\title{
Current status of habitat monitoring in the European Union according to Article 17 of the Habitats Directive, with an emphasis on habitat structure and functions and on Germany
}

\author{
Götz Ellwanger', Stephan Runge², Melanie Wagner², Werner Ackermann³, \\ Melanie Neukirchen', Wenke Frederking', Christina Müller', \\ Axel Ssymank', Ulrich Sukopp'
}

I Federal Agency for Nature Conservation, Konstantinstr. 110, 53179 Bonn, Germany 2 LB Planer+Ingenieure GmbH, Luftbild Brandenburg, Eichenallee 1a, 15711 Königs Wusterhausen, Germany 3 PAN Planungsbüro für angewandten Naturschutz GmbH, Rosenkavalierplatz 8, 81925 München, Germany

Corresponding author: Götz Ellwanger (goetz.ellwanger@bfn.de)

\begin{tabular}{l} 
Academic editor: S. Lengyel | Received 21 June 2018 | Accepted 13 September $2018 \mid$ Published 4 October 2018 \\
\hline http://zoobank.org/CB795315-B99F-4D69-A3AE-9EBDBD74A596 \\
Citation: Ellwanger G, Runge S, Wagner M, Ackermann W, Neukirchen M, Frederking W, Müller C, Ssymank A, \\
Sukopp U (2018) Current status of habitat monitoring in the European Union according to Article 17 of the Habitats \\
Directive, with an emphasis on habitat structure and functions and on Germany. Nature Conservation 29: 57-78. https:// \\
doi.org/10.3897/natureconservation.29.27273
\end{tabular}

\begin{abstract}
Since the beginning of the 1990s, monitoring of habitats has been a widespread tool to record and assess changes in habitat quality, for example due to land use change. Thus, Article 11 of the Habitats Directive (92/43/EEC) requires, inter alia, monitoring of the conservation status of habitat types listed in Annex I of the Habitats Directive, carried out by the Member States of the European Union (EU). This monitoring provides the foundation for the National Reports on the measures implemented and their effectiveness (Art. 17 Habitats Directive), which Member States have to submit to the European Commission every six years. Based on these requirements, Member States have developed different monitoring programmes or have adapted previously existing monitoring schemes to include relevant aspects of the Habitats Directive.

The parameter 'structure and functions' is a key parameter for the assessment of the conservation status of habitat types as it provides information on the quality of the habitats. A standardised questionnaire was developed and sent to the competent authorities of Member States to compare and analyse the assess-
\end{abstract}

Copyright Götz Ellwanger et al. This is an open access article distributed under the terms of the Creative Commons Attribution License (CC BY 4.0), which permits unrestricted use, distribution, and reproduction in any medium, provided the original author and source are credited. 
ment methods of the quality of habitat types. Responses were received from 13 of the 28 Member States, while it was possible to include another Member State in the analysis by evaluating appropriate literature.

The analysis revealed very different approaches and progress amongst the Member States in the development and implementation of monitoring programmes tailored to the reporting obligations of Article 17 of the Habitats Directive. Some Member States established a special standardised monitoring programme for Article 11 of the Habitats Directive, while others used data from already existing programmes (e.g. habitat mapping, large-scale forest inventories, landscape monitoring). Most Member States responding to the questionnaire use monitoring based on samples but the data collection, sample sizes and level of statistical certainty differ considerably. The same applies to the aggregation of data and the methods for the assessment of the parameter 'structure and functions'. In contrast to the assessment of conservation status as part of the reporting obligations according to Article 17 of the Habitats Directive, no standardised EU guidelines exist for monitoring. The present study discusses differences in the monitoring programmes and evaluates them with regard to the objectives of comparable assessments of conservation status of habitat types in the National Reports of Member States or at a biogeographical level.

\section{Keywords}

Habitats Directive, EU Member States, reporting, habitat type, structure and functions, assessment, biodiversity monitoring

\section{Introduction}

Monitoring of habitats has been a widespread tool for recording and assessing changes in habitat quality (e.g. due to land use change) since the beginning of the $1990 \mathrm{~s}$ (Lengyel et al. 2008a). This development is driven by international conventions on the protection of biodiversity like the Convention on Biological Diversity (CBD) as well as different directives of the European Union (EU) referring to biodiversity which include monitoring of habitats and species (Henle et al. 2013). For example, monitoring conservation status of habitat types listed in Annex I of the Habitats Directive (92/43/EEC) is mandatory according to Article 11 of the Directive. This provides the foundation for the National Reports on the measures implemented and their effectiveness (Art. 17 Habitats Directive) which Member States have to submit to the European Commission (EC) every six years. Based on these National Reports, the $\mathrm{EC}$ compiles a composite report which represents an essential basis for the achievement of biodiversity targets (EC 2011a).

The monitoring of habitat types required for the assessment of conservation status concentrates on a large-scale spatial level, namely the biogeographical regions of Europe (Evans 2012, ETC-BD 2006) or their respective proportions of the EU Member States. However, of the 150 investigated monitoring schemes for European habitats examined in the EuMon project, only $17.6 \%$ had a national scope, while the main part focused on a local (e.g. conservation areas) or regional level (e.g. administrative regions). Furthermore, most of these schemes addressed only one (44\%) or a few habitat types (Lengyel et al. 2008a, b). The EuMon database (http://eumon.ckff.si/monitoring/) currently (December 2017) contains 71 monitoring schemes from 11 EU Mem- 
ber States referring to the habitat types of the Habitats Directive. However, none of these monitoring schemes covers all habitat types of a Member State. It could be possible to combine several monitoring schemes, where appropriate, to a comprehensive monitoring system which includes all habitat types of the respective State.

The quality of the data for the National Reports according to the Habitats Directive still fluctuates considerably due to the ongoing need of Member States to develop targeted monitoring programmes or refine/complete existing programmes (de Bello et al. 2010, EEA 2015, EC 2015). The EU guidelines and reporting formats provide consistent cornerstones for appropriate monitoring programmes for all Member States (DG Environment 2017, EC 2016). The conservation status of habitat types is assessed by four parameters, which comprise quantitative ('range' and 'area' parameters) as well as qualitative ('structure and functions' parameter) criteria plus a forecast for the future ('future prospects' parameter) (EC 2016). An analysis of selective, nationwide mappings or recordings in conservation areas, some of which are also supported by remote sensing methods, provides data for the parameters range and area (e.g. Förster et al. 2008, Vanden Borre et al. 2011, 2017).

The assessment of habitat quality according to the requirements of the $\mathrm{EC}$ is based on the criteria 'habitat structures', 'habitat functions', 'typical species' and 'pressures and threats'. The criterion 'habitat structures' comprises physical components of a habitat type which are often formed by organisms (groups), including already dead organisms (e.g. standing or lying dead wood) as well as abiotic features (e.g. gravel banks for spawning). The criterion 'functions' means ecological processes which exist at a variety of temporal and spatial scales and differ considerably between habitat types (DG Environment 2017, p. 170). Typical species are those which mainly occur in a habitat type or at least in a subtype or a variant of a habitat type (DG Environment 2017 , p. 172f.). Thus, individual attributes (or subcriteria) have to be selected for each habitat type to assess habitat quality. For the investigation of these criteria, samplebased monitoring is appropriate, as already implemented by some Member States and prepared by others (e.g. Bijlsma and Jansen 2014, McConville and Tucker 2015, Moser and Ellmauer 2009, Sachteleben and Behrens 2010, Stöhr et al. 2014).

While standardised EU requirements exist for the assessment of conservation status as an evaluation matrix for the biogeographical level (EC 2016), common minimum EU standards are missing for the development and design of specific monitoring schemes (e.g. for sample sizes or statistical certainty). However, the evaluation matrix requires the detection of differences of $6 \%$ in one reporting period ( $1 \%$ per year). The evaluation matrix also lacks a threshold value for the maximum proportion of the area assessed as 'unfavourable' that is permissible for a favourable status of the parameter 'structure and functions'. Therefore, a comparative analysis of the different assessment methods of the parameter 'structure and functions' in the EU Member States was compiled. The aim of the project was to obtain references for a possible improvement of habitat monitoring in Germany. Here we present the results of the analysis and a comparative discussion. 


\section{Methods}

\section{Research and analysis of reporting data from Member States}

In a first step to find information on the approaches and methods of selected EU Member States concerning the assessment of the parameter 'structure and functions', an internet search was conducted for 15 countries which are part of the same biogeographical regions as Germany. The relevant data sources were considered regarding the accuracy of data aggregation and derivation of assessments, as well as validity of trends and amount of data (e.g. sample sizes for monitoring) and searched for further literature indications. Source documents were the Article 17 reports of Member States (EU obligations: Habitats Directive: Report on Implementation Measures) for the reporting period 2007-2012 (http://cdr.eionet.europa.eu), especially information on the 'most important achievements in the implementation of the Habitats Directive' (Annex A, field 1.1 or 1.2), as well as the collections of Internet links (especially field 2.3). German, English, French and Spanish homepages could be analysed directly, while information in other languages were examined for potentially relevant content by using translation aids like 'Google translate'. However, the internet search of publicly accessible documents did not yield sufficiently precise information on the assessment methodology used for the parameter 'structure and functions' for any of the selected Member States.

\section{Questionnaire to Member States}

In addition to the internet search, a standardised questionnaire was compiled for the selected EU Member States to answer essential questions. The questionnaire was in two parts (see Suppl. material 1: Table S1).

The first part focuses on sample selection and monitoring methods in general (e.g. monitoring scheme, number of habitat types monitored, number of sample plots, location of sample plots within or outside Special Areas of Conservation (SACs), utilisation of already existing monitoring systems).

The second part addresses assessment methods for the parameter 'structure and functions' at the level of biogeographical regions, based on the assessment of single habitat type occurrences (single plots). The objective of the analysis was to determine if Member States implement the assessment of conservation status based on individual habitat type occurrences (analogous to the standard data forms) similar to Germany or if the assessment is conducted based on other data.

The questionnaire contained 22 questions in total, as well as explanations on the approach in Germany. The questions related to monitoring in the reporting period 2007-2012, but some Member States have given outlooks for the current reporting period to show what will change. 
In mid-August 2015, the German Federal Agency for Nature Conservation (Bundesamt für Naturschutz, BfN), which is responsible at a national level for monitoring under Article 11 of the Habitats Directive, sent the questionnaire to members of the Expert Group on Reporting (EGR) and the Habitat Committee, overall to 26 of 28 Member States. Croatia was not included because the country only joined the EU in 2013. Representatives of 13 Member States (Austria, Belgium [only Wallonia], Czech Republic, Denmark, Finland, Hungary, Ireland, Latvia, Lithuania, Portugal, Romania, Slovenia and Sweden) answered the questionnaire. The authors of this paper compiled the answers for Germany.

Additionally, Bijlsma and Jansen (2014) yielded relevant aspects of the approach in the Netherlands. Information from the region of Wallonia has been used for Belgium, although assessment requirements and algorithms for conservation status differ in the regions of Flanders and Brussels (Westra et al. 2018).

The answers of the Member State representatives have been compiled in a table (as of May 2016, after queries to individual States), with their consent for publication of the data.

\section{Results}

\section{Answers from Member States}

Analysis of the questionnaires revealed that only two of the selected Member States (Portugal and Slovenia) had not yet carried out monitoring according to the Article 11 requirements in the reporting period 2007-2012. Slovenia planned to establish monitoring for Natura 2000 areas in 2015 for the first time. Only a little information on Slovenia has been available from other sources so far. Thus, replies to the questions have been omitted for these two countries. Finland only answered some of the questions.

The Czech Republic assesses data from a nationwide biotope mapping programme. The complete update of all data takes place there over 12 years. This means that only part of the data is newly collected for each reporting period.

\section{Was the assessment of the parameter 'structure and functions' for the biogeographical re-} gions conducted on the basis of a monitoring programme?

Most Member States assess the parameter 'structure and functions' by monitoring similar to Germany, at least for some of the habitat types. Wallonia (southern part of Belgium; four ecologically grouped monitoring schemes - forests, waters, grassland and other semi-natural open landscapes) and Denmark have implemented comprehensive monitoring programmes.

Monitoring programmes for a part of the habitat types or just subparameters exist in Finland, Ireland (monitoring schemes for ecological groups [e.g. upland 
habitat types, dune habitat types and raised bog habitat types]), Latvia, Romania (part of the forest habitat types as part of the nationwide forest inventory), Sweden (nationwide forest inventory; inland waters as part of monitoring according to the Water Framework Directive; Article 11 requirements are integrated into a general landscape monitoring which is still under development) and Hungary (grassland habitat types since 2009, forest habitat types since 2011, wetland habitat types since 2014).

Lithuania and Austria are still developing monitoring programmes. In Austria, the monitoring programme has so far only been tested in the forest inventory for forest habitat types. The Czech Republic does not conduct separate monitoring but uses repeated biotope mapping of their entire land area instead.

\section{I.a) When (year) was the monitoring programme installed?}

The starting points in time differ between Member States. The first monitoring was established in Wallonia (Belgium), where monitoring forests as part of the forest inventory has existed since 1994. The second monitoring was implemented in Hungary in 1997. Most Member States established their monitoring in the first decade of the $21^{\text {st }}$ century. Of course, older monitoring schemes for biotopes or landscapes existed in some Member States before the Habitats Directive came into force (e.g. the UK Countryside Survey).

The very different initialisation phases are a first indication of the varied development progresses and different methodical approaches of Member States. Like Germany, Denmark, Latvia and the Czech Republic used their monitoring results for the assessment of the parameter 'structure and functions' for the reporting period 20072012. In other countries, this has only been done for part of the habitat types (e.g. in Ireland) or has not yet been applied or just tested, as in Lithuania or Austria.

\section{I.b) In which biogeographical region is the monitoring programme carried out?}

Most of the Member States surveyed are conducting, or planning to carry out, a monitoring programme in all biogeographical regions. The marine parts of the biogeographical regions, which are recorded separately by the EC as marine regions, were not explicitly queried. So far, Ireland has conducted monitoring merely for the Atlantic region and the monitoring programme for marine-Atlantic habitat types only started in 2015 .

I.c) How many habitat types occur in your country? How many habitat types have been processed in the monitoring?

Depending on country size and biogeographical setting, the Member States surveyed have between 41 (Wallonia) and 89 (Sweden) habitat types. The States with an already existing monitoring programme include all or a majority of the terrestrial/inland 
habitat types in their respective programmes (minimum $87 \%$ of the habitat types in Hungary).

\section{I.d) Was the assessment conducted on selected sample plots or on the total habitat area (total} census)?

Most of the monitoring approaches are based, at least partly, on sampling as undertaken in Germany. The assessments of habitat types in Wallonia, Denmark, Ireland, Lithuania, Sweden and Hungary are conducted fully with samples. In Austria and Romania, selection is carried out similar to Germany on the basis of sampling for widespread habitat types and total census for rare habitat types. Finland uses sampling for widespread habitat types (e.g. 9010 and 9050). In Lithuania, monitoring is carried out in transects.

In the Netherlands, the conservation degree of each habitat type of each Natura 2000 site is considered, weighted according to its area in the site (Bijlsma and Jansen 2014, page 12) and it is assumed that the area of the habitat type outside Natura 2000 sites is very small. If this assumption proves to be false for a habitat type, one or two virtual Natura 2000 sites with an estimated degree of conservation are added. In the Czech Republic, the entire area is considered.

\section{I.e) What was the sample size per habitat type in each biogeographical region?}

In most Member States, the number of sampling areas depends on the frequency of habitat type and other ecological and methodical factors, as well as effort and costs. The other States do not apply a standardised sample size with an upper limit like the 63-sample in Germany. For frequent of habitat types, the number of samples and sample size generally exceed those in Germany to achieve the necessary accuracy of results. Table 1 lists detailed information on the samples in Member States.

\section{I.f) Which methods were used for the selection of sample plots (connected or unconnected, stratified or unstratified, weighted or unweighted samples)?}

Each Member State selected sample plots differently. Overall, most Member States conducted at least a partly systematic selection based on distribution, size and characteristics of habitat types and/or other factors. Random samples without an expert assessment of their representativeness have not been used by any Member State.

\section{I.g) Is the monitoring permanently repeated on the same sample plots once selected?}

Apart from Ireland, all Member States use permanent observation plots at least for the majority of investigated habitat types or a total inventory of habitat types as in the Czech Republic. 
Table I. Number of sampling areas for habitat types in Member States. BGR: biogeographical region; WFD: Water Framework Directive.

\begin{tabular}{|c|c|c|}
\hline $\begin{array}{l}\text { Member } \\
\text { State }\end{array}$ & $\begin{array}{c}\text { Minimum and maximum } \\
\text { number of sampling areas } \\
\text { per habitat }\end{array}$ & Explanations \\
\hline Austria & $60-100$ or total census & Depending on the variability and dynamic of the habitat type \\
\hline \multirow{3}{*}{$\begin{array}{l}\text { Wallonia } \\
\text { (Belgium) }\end{array}$} & \multirow{3}{*}{ No information } & $\begin{array}{l}\text { Forest habitat types as part of regional forest inventory - } 1 \text { sample } \\
\text { plot } / 50 \text { ha }\end{array}$ \\
\hline & & $\begin{array}{l}\text { Meadows - all habitat types in } 125 \text { quadrants of } 5 \mathrm{~km} \times 5 \mathrm{~km} \text { with } \\
\text { occurrences of the habitat type }\end{array}$ \\
\hline & & Water bodies - 440 sample sites in total as part of WFD \\
\hline $\begin{array}{l}\text { Czech } \\
\text { Republic }\end{array}$ & Total census & Consideration of total area \\
\hline Denmark & $200-3,000$ & $\begin{array}{l}\text { Between } 20 \text { and } 300 \text { sample locations (stations) with } 8-12 \text { sample } \\
\text { sites at each station for each habitat type }\end{array}$ \\
\hline \multirow{2}{*}{ Hungary } & \multirow{2}{*}{$1-530$} & $\begin{array}{l}\text { Number of samples for each habitat type proportional to coverage of } \\
\text { the habitat type }\end{array}$ \\
\hline & & $\begin{array}{l}\text { 4,800 samples in total, } 55 \% \text { for grassland habitat types, } 35 \% \text { for forest } \\
\text { habitat types, } 5 \% \text { for wetland habitat types, } 5 \% \text { for other habitat types }\end{array}$ \\
\hline Germany & 63 per BGR or total census & 5,128 sample plots for all habitat types in total \\
\hline \multirow[t]{2}{*}{ Ireland } & \multirow[t]{2}{*}{ Incomplete information } & $\begin{array}{l}\text { Representative sampling of national occurrences according to } \\
\text { geographical spectrum, e.g. } 60 \text { sites of old oak forest, } 40 \text { sites of dune } \\
\text { systems and } 25 \text { sites of meadows }\end{array}$ \\
\hline & & $\begin{array}{l}\text { Depending on size of sample plots, minimum of } 4 \text { sample sites } \\
\text { recommended }\end{array}$ \\
\hline Latvia & $1-224$ & 2,393 samples for all habitat types in total \\
\hline \multirow{2}{*}{ Lithuania } & \multirow{2}{*}{$1-100$} & $\begin{array}{l}\text { Spatial distribution based on quadrants with aim of covering at least } \\
10 \% \text { of national area }\end{array}$ \\
\hline & & $\begin{array}{l}\text { Thus, coverage of } 12-100 \% \text { of respective habitat types occurring in } \\
\text { the country }\end{array}$ \\
\hline Netherlands & No information & $\begin{array}{l}\text { All Natura } 2000 \text { sites of respective habitat type contribute to the } \\
\text { assessment, plus additional virtual sites if considerable occurrences } \\
\text { exist outside Natura } 2000\end{array}$ \\
\hline Romania & $20-1,000$ or total census & $\begin{array}{l}\text { Sample size per habitat type according to overall area of occurrences at } \\
\text { national level }\end{array}$ \\
\hline Sweden & No information & Depending on frequency of habitat type \\
\hline
\end{tabular}

\section{I.h) How often is the monitoring carried out (survey intervals) during one reporting period?}

Most Member States implemented at least one survey per reporting period. Several surveys per reporting period are mainly conducted in habitat types which depend on management, for example in Wallonia (aquatic monitoring) and Ireland (grassland). In the Czech Republic, one mapping cycle requires 12 years, thus only half of the land area is updated for each report. 
I.i) Were only Natura 2000 sites included in the monitoring or also sites outside the Natura 2000 network? Can differences insideloutside Natura 2000 be detected from the monitoring?

Most Member States included areas within and outside Natura 2000 sites. So far, none of the Member States could find statistically reliable differences or the sample size was not large enough to allow a differentiation. Only a few Member States (Wallonia, Czech Republic, Denmark, Finland, Hungary and Sweden) assume that this will be possible for the next reporting periods.

I.j) Are there already existing monitoring systems and are they used for the Article 11 monitoring?

In a few States, the data for the National Reports are based on different monitoring systems and data. Monitoring according to Article 11 has been partly integrated into already existing procedures or only data has been extracted from already existing procedures. Independent monitoring programmes specially developed for Article 11 monitoring exist merely in a few countries (Germany, Denmark, Latvia, as well as the Czech Republic). Austria is currently developing Article 11 monitoring.

II.a) How is the evaluation of single habitat plots (degree of conservation) included in the assessment of the parameter 'structure and functions' as part of conservation status at biogeographical level?

The assessments of single monitoring plots are integrated into the assessment of the parameter 'structure and functions' in all examined monitoring approaches. However, the employed methods differ between States and are elaborated in the following questions. Table 2 shows a summary of all answers.

II.b) Is there a uniform assessment scheme for each habitat type on site or plot level in your State?

Wallonia, Germany, Denmark, Latvia, Lithuania, the Netherlands, Austria, Romania, Sweden, the Czech Republic and Hungary have a standardised assessment scheme. Denmark, Hungary and Germany revised their schemes for the reporting period 2013-2018. In Ireland, the assessment methods for each habitat type are similar but not always the same because different approaches work better for some habitat types depending on the heterogeneity of habitat type. Some countries, like Sweden or Hungary, have standardised assessment schemes for groups of habitat types, such as forest and grassland habitat types. 
II.c) If no uniform assessment scheme exists: How is the evaluation of habitat types carried out?

Most Member States have standardised assessment schemes. In Hungary, assessment schemes are lacking only for a few habitat types. For these habitat types, experts conduct the assessment by using other data from nationwide biodiversity monitoring. In Sweden, habitat types without standardised assessment schemes are evaluated by experts based on existing data and expert opinion.

II.d) How is the review of the criterialthe degree of conservation on site or plot level carried out?

Except for Wallonia (Belgium), Member States calculated a degree of conservation (as in Germany) or a comparable assessment for each sample plot. In Wallonia, all features are aggregated at a biogeographical level and combined afterwards to a degree of conservation.

II.e) How was the assessment of the typical species referred to in Appendix V of the guidelines (Assessment and reporting under Article 17 of the Habitats Directive, Explanatory Notes \& Guidelines) carried out for the period 2007-2012)? Which species groups were investigated?

The considered Member States, except for the Netherlands and Sweden, investigated plant species only; animal species are solely considered for assessment in special cases or as additional information. Member States either apply complete species lists or just use species typical for a habitat type or indicator species. In Germany, the assessment of habitat types dominated by vegetation is also conducted solely via number of typical plant species. Animal groups are included in the assessment of a few habitat types only (see question II.g in Suppl. material 1: Table S1).

II.f) What method for monitoring the vegetation is recognized: Compilation of a complete list of species, phytosociological relevés recording according to Braun-Blanquet, or other methods?

Many Member States compile, at least for some habitat types, lists of typical species. Only Denmark records complete species lists and three Member States perform phytosociological vegetation mapping (Wallonia, Ireland, Lithuania).

II.g) Is a faunistic list also recorded - a complete list or only for certain groups of species? From which faunistic groups are typical species recorded?

Most Member States rarely used animal species, especially for assessment of habitat types with sparse or no vegetation of higher plants. Only Sweden lists animal species for assessment of a few habitat types. The most frequent animal groups are birds, butterflies and beetles (see also question II.e). 
II.h) Are the assessments of the criteria 'habitat structures', 'typical species', and 'pressures and threats' calculated separately for all sample plots? Or is the separately calculated degree of conservation of each sample plot used for aggregation?

Germany, Denmark, Ireland, Latvia, Austria, the Czech Republic and Hungary aggregate the degree of conservation which has been calculated for each sample plot separately. Denmark is revising the method for calculating conservation status for the next report according to Article 17. Ireland is testing another method with an indicator-based instead of plot-based assessment. For this method, individual features or criteria of many sample plots are directly aggregated at a biogeographical level without combining all relevant features or criteria of a single sample plot to a degree of conservation. Similar assessments are already underway in Sweden. In Wallonia, assessments of some features are aggregated at the biogeographical level, while others are aggregated at the level of single sample plots.

In the Netherlands, the conservation degree of a habitat type (based on the requirements of the standard data forms) of each SAC is assessed separately and conservation degrees of respective habitat type of several SACs are subsequently aggregated according to their area percentage (see question II.d).

\section{II.i) How is the parameter 'structure and functions' calculated at biogeographical level?}

From the information supplied, it is concluded that four different approaches can be distinguished regarding the methods of Member States (see Table 2):

- Holistic assessment of single plots or single Natura 2000 sites and aggregation of the parameter 'structure and functions' according to a threshold for percentage of single assessments (Denmark, Wallonia - grassland habitat types, Ireland, Latvia, Austria, Romania, Czech Republic). This corresponds to monitoring of sample plots in Germany and assessment of the parameter 'structure and functions' according to the proportion of $\mathrm{C}$ assessments of conservation degree.

- Calculation of an assessment at a biogeographical level of each individual feature and subsequent derivation of the parameter 'structure and functions' (Wallonia - forest habitat types). In Germany, a consistent value at a biogeographical level is only determined for the features 'forest development phase', 'habitat trees' and 'dead wood' of frequent forest habitats which are assessed based on data from the National Forest Inventory.

- Expert evaluation of the parameter 'structure and functions' without fixed rules for aggregation but based on individual features of all sample plots (Sweden). This method was occasionally used in Germany if monitoring would have resulted in 'unknown' for some reasons (missing data for a part or all of sample plots).

- Assessment of conservation degrees in single Natura 2000 sites and aggregation to a status of the subparameter 'structure and functions (without typical species)' according to a threshold value for the area percentages of conservation degrees at a 
Table 2. Assessment of parameter 'structure and functions' in Member States - row colours: violet - assessment at single plot level, blue - assessment at Natura 2000 site level, orange - assessment at biogeographical level.

\begin{tabular}{|c|c|c|c|c|c|}
\hline $\begin{array}{l}\text { Member } \\
\text { State }\end{array}$ & $\begin{array}{l}\text { Habitat } \\
\text { types }\end{array}$ & $\begin{array}{l}\text { Threshold for } \\
\text { favourable status } \\
\text { FV ('green') }\end{array}$ & \begin{tabular}{|c|} 
Threshold for \\
unfavourable- \\
inadequate status \\
U1 ('yellow') \\
\end{tabular} & $\begin{array}{c}\text { Threshold for } \\
\text { unfavourable-bad status } \\
\text { U2 ('red') }\end{array}$ & Explanations \\
\hline Austria & All & $\begin{array}{l}\text { A-proportion } \\
\geq 50 \% \text { and } \\
\text { C-proportion < } \\
33.3 \%\end{array}$ & $\begin{array}{l}\text { All other } \\
\text { combinations }\end{array}$ & $\begin{array}{l}\text { C-proportion }>33.3 \% \\
\text { and A-proportion }<50 \%\end{array}$ & $\begin{array}{l}\text { Assessment of conservation } \\
\text { degrees of single plots }\end{array}$ \\
\hline $\begin{array}{l}\text { Wallonia } \\
\text { (Belgium) }\end{array}$ & Forest & $\begin{array}{l}\text { All three criteria } \\
\text { (structure, } \\
\text { functions, } \\
\text { regeneration) at } \\
\text { biogeographical } \\
\text { level FV }\end{array}$ & $\begin{array}{l}\text { At least one } \\
\text { criterion at } \\
\text { biogeographical } \\
\text { level U1 and no } \\
\text { criterion U2 }\end{array}$ & $\begin{array}{l}\text { At least one criterion at } \\
\text { biogeographical level U2 }\end{array}$ & $\begin{array}{l}\text { Assessment of each feature } \\
\text { of single plots } \rightarrow \text { averaging } \\
\text { all assessments of a feature } \\
\text { at biogeographical level }(\mathrm{C} \\
\text { weighted more strongly: } \mathrm{A}=1, \\
\mathrm{~B}=2 \text { and } \mathrm{C}=4) \rightarrow \mathrm{FV}<1.5< \\
\mathrm{U} 1<2.5<\mathrm{U} 2\end{array}$ \\
\hline $\begin{array}{l}\text { Wallonia } \\
\text { (Belgium) }\end{array}$ & Grassland & No information & No information & No information & $\begin{array}{l}\text { Assessment of conservation } \\
\text { degrees of single plots }\end{array}$ \\
\hline $\begin{array}{l}\text { Czech } \\
\text { Republic }\end{array}$ & All & $\begin{array}{l}<10 \% \text { of partial } \\
\text { areas assessed as } \\
\text { 'less favourable' and } \\
\text { 'unfavourable' }\end{array}$ & $\begin{array}{l}10-25 \% \text { of partial } \\
\text { areas assessed as } \\
\text { 'less favourable' } \\
\text { and 'unfavourable' }\end{array}$ & $\begin{array}{l}>25 \% \text { of partial areas } \\
\text { assessed as 'less favourable' } \\
\text { and 'unfavourable' }\end{array}$ & $\begin{array}{l}\text { Assessment of conservation } \\
\text { degrees of single plots }\end{array}$ \\
\hline Denmark & All & $\begin{array}{l}>50 \% \\
\text { A-proportion } \\
\text { and }>75 \% \\
\text { A+B-proportion } \\
(=\text { C-proportion } \\
<25 \% \text { and } \\
\text { A-proportion > } \\
50 \%)\end{array}$ & $\begin{array}{l}\text { All other } \\
\text { combinations }\end{array}$ & $\begin{array}{l}<25 \% \text { A-proportion and } \\
<50 \% \text { A+B-proportion } \\
(=\text { C-proportion }>50 \% \\
\text { and A-proportion }<25 \%)\end{array}$ & $\begin{array}{l}\text { Assessment of conservation } \\
\text { degrees of single plots }\end{array}$ \\
\hline Germany & All & $\begin{array}{l}\text { C-proportion } \leq \\
20 \%\end{array}$ & $\begin{array}{l}\text { C-proportion } \\
>20 \text { and } \leq 25 \%\end{array}$ & C-proportion $>25 \%$ & $\begin{array}{l}\text { Assessment of conservation } \\
\text { degrees of single plots }\end{array}$ \\
\hline Hungary & All & No information & No information & No information & $\begin{array}{l}\text { Assessment of conservation } \\
\text { degrees of single plots. } \\
\text { Naturalness-based habitat quality } \\
\text { index (Németh and Seregélyes } \\
1989 \text { ) }\end{array}$ \\
\hline Ireland & All & C-proportion $<1 \%$ & $\begin{array}{l}\text { C-proportion } \\
1-25 \%\end{array}$ & C-proportion $>25 \%$ & $\begin{array}{l}\text { Assessment of conservation } \\
\text { degrees of single plots }\end{array}$ \\
\hline Latvia & All & No information & No information & No information & $\begin{array}{l}\text { Assessment of conservation } \\
\text { degrees of single plots (no } \\
\text { assessment if total area of habitat } \\
\text { type decreases }>1 \% \text { per year } \\
\text { during one reporting period) }\end{array}$ \\
\hline Lithuania & All & No information & No information & No information & $\begin{array}{l}\text { Assessment of conservation } \\
\text { degree at Natura } 2000 \text { site level }\end{array}$ \\
\hline Netherlands & All & $\begin{array}{l}\text { If A-proportion } \\
\geq 75 \% \text { and } \\
\text { C-proportion } \leq \\
15 \%\end{array}$ & $\begin{array}{l}\text { All other } \\
\text { combinations }\end{array}$ & $\begin{array}{l}\text { C-proportion }>25 \% \text { and } \\
\mathrm{A}<\mathrm{B}+\mathrm{C}\end{array}$ & $\begin{array}{l}\text { Assessment of subparameter } \\
\text { 'structure and functions (without } \\
\text { typical species)' at Natura } 2000 \\
\text { site level }\end{array}$ \\
\hline Netherlands & All & $\begin{array}{l}\text { Proportion of } \\
\text { FV } \geq 75 \% \text { and } \\
\text { proportion of } \\
\mathrm{U} 2 \leq 15 \%\end{array}$ & $\begin{array}{l}\text { All other } \\
\text { combinations }\end{array}$ & $\begin{array}{l}\text { Proportion of } \mathrm{U} 2>25 \% \\
\text { and proportion of } \mathrm{FV} \\
<\text { proportion of } \\
(\mathrm{U} 1+\mathrm{U} 2)\end{array}$ & $\begin{array}{l}\text { Assessment of subparameter } \\
\text { 'typical species' at } \\
\text { biogeographical level in relation } \\
\text { to proportion of species } \\
\text { belonging to different species } \\
\text { groups according to Red List }\end{array}$ \\
\hline
\end{tabular}




\begin{tabular}{l|l|l|l|l|l}
\hline $\begin{array}{c}\text { Member } \\
\text { State }\end{array}$ & $\begin{array}{c}\text { Habitat } \\
\text { types }\end{array}$ & $\begin{array}{c}\text { Threshold for } \\
\text { favourable status } \\
\text { FV ('green') }\end{array}$ & $\begin{array}{c}\text { Threshold for } \\
\text { unfavourable- } \\
\text { inadequate status } \\
\text { U1 ('yellow') }\end{array}$ & $\begin{array}{c}\text { Threshold for } \\
\text { unfavourable-bad status } \\
\text { U2 ('red') }\end{array}$ & \multicolumn{1}{c}{ Explanations } \\
\hline Netherlands & All & $2 \times \mathrm{FV}$ & At least $1 \times \mathrm{U} 1$ & At least $1 \times \mathrm{U} 2$ & $\begin{array}{l}\text { Assessment of conservation } \\
\text { status by aggregating assessments } \\
\text { of subparameter 'structure } \\
\text { and functions (without typical } \\
\text { species)' and 'typical species' at } \\
\text { biogeographical level according } \\
\text { to EU evaluation matrix }\end{array}$ \\
\hline Romania & All & $\begin{array}{l}\text { C-proportion } \\
<20 \% \text { and } \\
\text { A-proportion } \geq \\
50 \%\end{array}$ & $\begin{array}{l}\text { All other } \\
\text { combinations }\end{array}$ & $\begin{array}{l}\text { A-proportion } \geq 50 \% \text { and } \\
\text { A-proportion }<20 \%\end{array}$ & $\begin{array}{l}\text { Assessment of conservation } \\
\text { degrees of single plots }\end{array}$ \\
\hline Sweden & All & - & - & - & Expert evaluation \\
\hline
\end{tabular}

biogeographical level. Furthermore, determination of the status of the subparameter 'typical species' at a biogeographical level based on the categories of the Red List of all typical species and subsequent aggregation of both subparameters at a biogeographical level to the parameter 'structure and functions (including typical species)' according to the EU evaluation matrix. Only the Netherlands uses this method.

Although most Member States apply the first method, considerable differences exist between threshold values (see Table 2 and section 3.2). In Wallonia, the first two methods are used.

II.j) What is the significance and the statistical power of the monitoring/the assessment? How big is the minimum detectable difference between two reporting cycles (six years)?

None of the Member States surveyed made a statement on theoretical statistical strength of the samples or the monitoring. Either they did not understand the question or no calculations exist. The question did not aim at complete determined differences, but at the size of possibly detectable differences between two reporting periods.

Germany specified a significance level ( $\alpha$ error) and a $\beta$ error of 0.2 each. The power is 0.8 . The applied $\mathrm{Chi}^{2}$ test yielded a minimum detectable difference of $\geq 30 \%$ for a sample size of 63 (Sachteleben and Behrens 2010).

\section{II. k) Are reference documents or websites available for methods used? Is it possible to provide digital documents?}

The information and further literature of Member States differ considerably. Additional information on Article 17 methodology beyond the questionnaire replies is not included. Lithuania, Denmark and Hungary only have information in their respective national language. The Czech Republic added all relevant information which has been integrated into the answers above. For the Netherlands, the documents from Bijlsma and Jansen (2014) and Jansen et al. (2014) were analysed. 


\section{Assessment at biogeographical level}

Besides the design of data collection (questions to point I), the assessment methods of the parameter 'structure and functions' at a biogeographical level are also particularly important. The approaches of Member States differ considerably (see Table 2). However, most Member States who replied use the three grades of the EU assessment system for the conservation degree. The assessment of the degree of conservation comprises three grades: A - excellent; B - good; and C - average or bad. Some States assess degrees of conservation at the level of single plots; others assess degrees of conservation of habitat type areas in the respective Natura 2000 sites (Netherlands) and some States evaluate subparameters for assessment of the structure and functions directly at site or biogeographical level (Ireland, Wallonia - e.g. structural diversity in forests). Sometimes, experts are consulted in borderline cases or for subparameters which are difficult to obtain.

Only four Member States (Germany, Ireland, Netherlands, Czech Republic) apply the threshold value defined in the reporting format for an inadequate-bad status if more than $25 \%$ of the area is inadequate (Table 2), but in the Netherlands, it is linked to additional conditions. Another three Member States (Denmark, Austria, Romania) also assess the proportion of $\mathrm{C}$ assessments but use different threshold values and consider the proportion of A assessments as well.

The $25 \%$ specification of the reporting format is unclear if individual features are assessed at a biogeographical level and then aggregated to the criteria or directly to the parameter 'structure and functions'. Although it is possible to aggregate individual features according to their proportion (based on area or quantity) of the respective assessments (A, B or C), Member States can decide if one or more features of a criterion have to exceed $25 \%$ for a U2 assessment of the criterion.

If assessment of the individual features of conservation degrees is conducted by averaging for assessment of the three features of the criterion 'species composition of the vegetation' (as in Wallonia), the proportion of A assessments partly balances the C assessments. Thus, the 'unfavourable' status of a feature shows only with a much higher proportion of $\mathrm{C}$ assessments. The described example of Wallonia tries to compensate for this effect by weighting the proportion of $\mathrm{C}$ assessments higher than the other assessments.

An assessment of single features of the parameter 'structure and functions' may not be appropriate at the level of single plots (e.g. proportion of dead wood or habitat trees on very small sample plots of a few $100 \mathrm{~m}^{2}$ ). In this case, averaging of the value of the feature is conducted for all sample plots (e.g. forest habitat types in Wallonia, frequent forest habitat types in Germany). The assessment is ultimately carried out via a threshold for the calculated average values. In these cases, it is not possible to apply the $25 \%$ rule.

\section{Discussion}

Our analysis of relevant monitoring programmes of EU Member States reveals considerable differences in the interpretation and application of monitoring 
according to Article 11 of the EU Habitats Directive and, thus, differences in the quality and quantity of monitoring data used for assessment of conservation status of habitat types. Only a few of the States who replied (Wallonia, Denmark, Germany, Hungary, Ireland) have established and already applied a special, standardised monitoring programme according to Article 11. Some States have used data from existing monitoring programmes (e.g. large-scale forest inventories: Wallonia, Austria, Romania, Sweden, Germany [for 5 frequent forest habitat types]; landscape monitoring in Sweden) for monitoring according to Article 11. Many States are still developing or implementing their monitoring schemes (e.g. Austria, Lithuania) or revising it (e.g. Sweden - landscape monitoring).

Monitoring of structure and functions of a habitat type targets the determination of significant changes in conservation status. For its sample plots, each Member State defines which type of changes it specifically investigates, the criteria or indicators used for the analysis, the number of repetitions (in a reporting period) and the extent of tolerable changes in criteria/indicators. Thus, it is impossible to combine assessments of sample plots from different Member States at a biogeographical level or compare them directly.

An overall monitoring programme in all Member States would have many potential advantages but it would result in an enormous effort of coordination and development, not least because of very different manifestations of many broadly defined habitat types (e.g. regarding their floristic composition) within their European distribution area (compare Bunce et al. 2013 on the field identification of habitat types). Nevertheless, we recommend regional cross-border cooperation, especially for implementation of a monitoring programme in small Member States or if a Member State has only a small proportion of a biogeographical region. Thus, disproportionate effort in areas with a small occurrence of a habitat type can be avoided without completely foregoing monitoring in these parts. An analogous cooperation has been suggested for the Alpine region of Austria and Germany (Bavaria) (National Report 2013).

Lengyel et al. (2008b) describe the essential requirements for integration of data and monitoring schemes. The most important foundation is a consistent typology of habitat types, as mostly given in the Habitats Directive (EC 2013, Evans 2006; see Evans 2010 on the differences between Member States). In Germany, this typology of habitat types enabled joint monitoring of habitats conducted by the Federal States in the first place (Sachteleben and Behrens 2010). The Federal States had been developing their own classifications for decades before the Habitats Directive was implemented (Riecken et al. 2003). Various vegetation classifications have also been developed at the regional/national level of the European States, which form the basis for the definition of habitats and may only be partially compatible with the recently published European checklist (Mucina et al. 2016).

Most Member States apply sample-based monitoring schemes which are based on field mapping of single occurrences of specified target habitats ('field mapping-based, targeted monitoring schemes' sensu Lengyel et al. 2008a). The survey method in the field and the design of sample plots are very important for comparability and integration of results of monitoring schemes. 
The number of sample plots per habitat type and methods of selecting samples differ considerably between Member States. The number of sample plots depends mainly on the frequency of a habitat type in most Member States. Sample plots are partly selected systematically based on criteria such as spatial distribution, size or manifestation of habitat types, while the representativeness of plots is usually evaluated by an expert.

This analysis did not include the application of remote sensing methods for monitoring the structure and functions of habitat types. Nevertheless, it can be assumed that remote sensing methods are used only sporadically in inaccessible regions (e.g. high mountains in the Alpine region), apart from the application of aerial images for mapping of habitat types. On the one hand, it is almost impossible to recognise habitat types even with satellite data; on the other hand, the responsible project managers so far lack access to the necessary data, computing capacity, standardised analysing tools and specific knowledge. The rapid development in this field could possibly lead to many innovations, as well as in monitoring of habitats (e.g. Buck et al. 2015, Corbane et al. 2015, Schmidt et al. 2017, Vanden Borre et al. 2017).

The individual Member States (or even sub-regions like Wallonia in Belgium) also define the criteria and thresholds for assessment of the quality of single occurrences of habitat types. Although the EC was able to provide a standardised reporting format for the reporting period 2001-2006, as required by the Habitats Directive, further development of this format, including some methodical harmonisations, required long and comprehensive preparations by EU working groups for both subsequent reports. Thus, it seems unlikely that the detection of changes in habitat types at the level of single sample plots could be successfully standardised for many Member States or complete biogeographical regions. Even though methodical approaches of European monitoring of habitats have been developed (Bunce et al. 2005, Brus et al. 2011, Metzger et al. 2013), they focused on common habitats or general ecosystem monitoring. Therefore, integration of previously existing Member State monitoring schemes is the preferable option (see Henry et al. 2008).

Harmonisation/integration could be achieved by standardisation of derivation methods of the overall assessment of the parameter 'structure and functions' at a biogeographical level by Member States. Most Member States who replied have standardised schemes for assessment of the conservation degree of single sample plots. The degree of conservation is defined by the EU decision on the standard data forms of the SACs and is composed of three criteria: 'conservation degree of the structure (including typical species)'; 'conservation degree of the functions'; and 'restoration possibility' (EC 2011b). The criteria of Member States partially comply with the EU definition, but mostly pick up the three grades of the EU assessment system (see section 3.2). Thus, overall assessment of all sample plots at a biogeographical level offers the best chance to harmonise assessment methods.

The evaluation matrix according to Annex E of the reporting format (EC 2016) is essential for this final assessment step, in this context for the parameter 'structure and functions'. It defines the status of the structure and functions of a habitat 
type as favourable if all the criteria mentioned above are assessed as good and no significant deterioration or pressures exist. An unfavourable status is subdivided into 'unfavourable-inadequate' and 'unfavourable-bad'. The latter is attained if more than $25 \%$ of the area of a habitat type is evaluated as 'unfavourable' regarding structure and functions (including typical species). Some Member States deviate from these specifications (see 3.2). The 25\% threshold is sometimes ignored, sometimes replaced or supplemented by minimum proportions of sample plots with 'excellent status (A)'. The inclusion of proportion of sample plots with an A status into the assessment seems appropriate considering the protection of habitat type. The changes in A-plots to B-plots, which do not affect the assessment if only the $\mathrm{C}$ proportion is considered, still constitute a deterioration in status of a habitat type. Furthermore, A-plots can substitute (regarding their function) C-plots only if these are in close spatial proximity. Thus, it is critical to comply with the prescribed maximum $\mathrm{C}$ proportions solely mathematically regarding comparability of the results of Member States. The matrix does not contain a threshold for the definition of a favourable status which has led to values between 1\% and 20\% for the proportion of $\mathrm{C}$ assessments in Member States. The EC suggests an area proportion of $90 \%$ with a 'good' status of structure and functions (DG Environment 2017). As this was controversial within Member States, the threshold value for the next reporting period is expected to be discussed again.

Our analysis also revealed that consideration of animal species is a weak point in monitoring schemes of habitat types in almost all Member States. This contradicts the definition of 'conservation status of a natural habitat' according to Article 1e) of the Habitats Directive, which states that the conservation status of a habitat type is favourable if, inter alia, the conservation status of the typical species of this habitat type are favourable. This definition includes animal species, but also fungi, which are presumably also not, or hardly taken into account in monitoring programmes.

Another difficulty of monitoring schemes is that sample plots may be selected regarding the number and distribution of occurrences, but regardless of widely varying area sizes of different occurrences of a habitat type. At least in Germany, this is the case and leads to a lack of representativeness in terms of total distribution area of a habitat type. The different quantities of sample plots per habitat type both absolute and concerning the relative size of a Member State have been mentioned already. Furthermore, in most Member States, no information is available on statistical robustness regarding the detectability of changes in status of a habitat type (in two or more reporting periods) based on the analysed samples. For assessment of conservation status of a habitat type, information on occurrences inside conservation areas as well as outside these areas is necessary. Thus, most Member States consider sample plots within and outside their protected areas in their monitoring schemes. No Member State has been able to detect statistically robust differences so far, but some expect to do so in the next reporting periods.

A European-wide analysis (meta-analysis), considering data from different national monitoring programmes based on one or more indicators (e.g. completeness 
of the species inventory, habitat quality) or trends, could possibly result in improved assessment of habitat types at a biogeographical level in the EU. Thus, it could be possible to enhance the sample size, the accuracy of estimation (e.g. of trends), temporal coverage and probably statistical power without increasing the number of sample plots within Member States (Henry et al. 2008). An appropriate evaluation method remains to be developed and will need to take account of different sample designs (number and selection of sample plots), for example by weighting (post stratification). Henry et al. (2008) discuss methodical approaches to that. It has to be determined if the usage of classes (A-B-C assessment of the sample plots), which have been calculated based on different indicators, enables a sufficiently precise detectability of changes in status of habitat types.

Nevertheless, Member States are obliged to fill the gaps in geographical coverage of single habitat types, i.e. to develop monitoring programmes at a national level where they are still missing. To improve comparability of results of assessments of a habitat type between Member States, simple minimum requirements regarding sample size and assessment methods for biogeographical regions (within the Member States) should be agreed upon at the EU level.

From the authors' point of view, the following points describe best practices implemented so far and emerge as potential recommendations for sample-based habitat monitoring for the parameter 'structure and functions':

- assessment of all habitat types of a Member State according to individual assessment schemes, separated by biogeographical regions,

- sufficiently large sample size to be able to estimate changes in condition of a habitat type with sufficient certainty (Denmark appears exemplary here),

- stratification of samples according to the areal proportion of habitat types and whether they are located within or outside the SACs,

- survey of habitat types on fixed permanent sampling plots,

- examination of each sampling plot at least in one year of each reporting period, several times in the case of anthropozoogenic habitat types which respond quickly to changing land use or pressures,

- consideration of typical plant species at least by means of roughly quantified species lists or vegetation surveys,

- consideration of typical animal species of well-known groups of species with a known indicator function in the assessment of habitat types,

- normally, status of a habitat type is evaluated first at the level of the sample areas and then aggregated at the level of the biogeographical region.

Currently there is no monitoring programme for any of the Member States examined that already covers all these points. However, some recommendations are already being implemented in some Member States' monitoring programmes. Further points to consider in the evaluation of habitat monitoring programmes, including benchmarks to compare current practices, can be found in Lengyel et al. (2018). 


\section{Acknowledgements}

This research was funded by the German Federal Agency for Nature Conservation (BfN) with financial resources of the Federal Ministry for the Environment, Nature Conservation and Nuclear Safety (Research and Development project 'Adaptation and development of the methods for the compilation of the National Report according to Article 17 of the Habitats Directive', FKZ 351482 0600).

We would like to especially thank the representatives of the Member States who took the time to answer the questionnaire, sometimes in great detail. Austria: Thomas Ellmauer and Alexander Schuster; Czech Republic: Karel Chobot; Denmark: Jesper Fredshavn; Ireland: Deirdre Lynn; Finland: Olli Ojala; Hungary: Kinga Bata and Ildikó Varga; Latvia: Gita Strode; Lithuania: Algirdas Klimavičius; Portugal: Helena Ceia; Romania: Iovu Biris; Slovenia: Matej Petkovšek; Sweden: Anders Jacobson; Wallonia (Belgium): Jean Marc Couvreur and Lionel Wibail. We would also like to thank the reviewers Doug Evans and Szabolcs Lengyel for their valuable comments on the manuscript. We thank Mark Sixsmith for his linguistic correction of the manuscript.

\section{References}

Bijlsma RJ, Jansen JAM (2014) Structuur en functie van habitattypen; Onderdeel van de documentatie van Habitatrichtlijn artikel 17-rapportage 2013. Wettelijke Onderzoekstaken Natuur \& Milieu, WOt-technical report 33: 1-42. http://edepot.wur.nl/341898

Brus DJ, Knotters M, Metzger MJ, Walvoort DJJ (2011) Towards a European-wide sampling design for statistical monitoring of common habitats. Alterra report 2213: 1-66. https:// www.wur.nl/upload_mm/4/0/9/3c60c015-861e-46cc-85fc-b54d969f3f6a_EBONED33TowardsaEuropeanwidesamplingdesign.pdf

Buck O, García Millán VE, Klink A, Pakzad K (2015) Using information layers for mapping grassland habitat distribution at local to regional scales. International Journal of Applied Earth Observation and Geoinformation 37: 83-89. https://doi.org/10.1016/j. jag.2014.10.012

Bunce RGH, Bogers MMB, Evans D, Jongman RHG (2013) Field identification of habitats directive Annex I habitats as major European biodiversity indicator. Ecological Indicators 33: 105-110. https://doi.org/10.1016/j.ecolind.2012.10.004

Bunce RGH, Groom GB, Jongman RHG, Padoa-Schioppa E (Eds) (2005) Handbook for Surveillance and Monitoring of European Habitats. Alterra report 1219: 1-107. http://library. wur.nl/WebQuery/wurpubs/fulltext/30274

Corbane C, Lang S, Pipkins K, Alleaume S, Deshayes M, García Millán VE, Strasser T, Vanden Borre J, Spanhove T, Förster M (2015) Remote sensing for mapping natural habitats and their conservation status - New opportunities and challenges. International Journal of Applied Earth Observation and Geoinformation 37: 7-16. https://doi.org/10.1016/j. jag.2014.11.005 
de Bello F, Lavorel S, Gerhold P, Reier U, Pärtel M (2010) A biodiversity monitoring framework for practical conservation of grassland and shrublands. Biological Conservation 143(1): 9-17. https://doi.org/10.1016/j.biocon.2009.04.022

DG Environment (2017) Reporting under Article 17 of the Habitats Directive: Explanatory notes and guidelines for the period 2013-2018. Final version - May 2017. Brussels: 1-188. http://cdr.eionet.europa.eu/help/habitats_art17/index_html

EC/European Commission (2011a) The EU Biodiversity Strategy to 2020. Publications Office of the European Union, Luxembourg, 1-27. https://doi.org/10.2779/39229

EC/European Commission (2011b) Commission Implementing Decision of 11 July 2011 concerning a site information format for Natura 2000 sites (notified under document $\mathrm{C}(2011)$ 4892) (2011/484/EU). Official Journal of the European Union L 198: 39-70. http://eurlex.europa.eu/legal-content/EN/TXT/PDF/?uri=CELEX:32011D0484\&from=EN

EC/European Commission (2013) Interpretation Manual of European Union habitats. EUR 28: 1-144. http://ec.europa.eu/environment/nature/legislation/habitatsdirective/docs/ Int_Manual_EU28.pdf

EC/European Commission (2015) The state of Nature in the European Union. Report on the status of and trends for habitat types and species covered by the Birds and Habitats Directives for the 2007-2012 period as required under Article 17 of the Habitats Directive and Article 12 of the Birds Directive. Brussels (COM(2015) 219 final): 1-19. http://eur-lex. europa.eu/legal-content/EN/TXT/PDF/?uri=CELEX:52015DC0219\&from=EN

EC/European Commission (2016) Reporting under Article 17 of the Habitats Directive. Report format for the period 2013-2018, Final Version - November 2016, Brussels, 1-29. http://cdr.eionet.europa.eu/help/habitats_art17/index_html

EEA/European Environment Agency (2015) State of nature in the EU. Results from reporting under the nature directives 2007-2012. EEA Technical report No 2/2015: 1-173. https:// www.eea.europa.eu/publications/state-of-nature-in-the-eu

ETC-BD/European Topic Centre on Biological Diversity (2006) The Indicative Map of European Biogeographical Regions: Methodology and Development. http://www.eea.europa. eu/data-andmaps/data/biogeographical-regions-europe-2005/methodology-descriptionpdf-format/methodology-description-pdf-format/at_download/file

Evans D (2006) The habitats of the European Union Habitats Directive. Biology and Environment 106B(3): 167-173. https://doi.org/10.3318/BIOE.2006.106.3.167

Evans D (2010) Interpreting the habitats of Annex I - Past, present and future. Acta Botanica Gallica 157(4): 677-686. https://doi.org/10.1080/12538078.2010.10516241

Evans D (2012) Building the European Union's Natura 2000 network. Nature Conservation 1: 11-26. https://doi.org/10.3897/natureconservation.1.1808

Förster M, Frick A, Walentowski H, Kleinschmit B (2008) (2008) Approaches to utilising QuickBird data for the monitoring of Natura 2000 habitats. Community Ecology 9(2): 155-168. https://doi.org/10.1556/ComEc.9.2008.2.4

Henle K, Bauch B, Auliya M, Külvik M, Pe'er G, Schmeller DS, Framstad E (2013) Priorities for biodiversity monitoring in Europe: A review of supranational policies and a novel scheme for integrative priorization. Ecological Indicators 33: 5-18. https://doi. org/10.1016/j.ecolind.2013.03.028 
Henry P-Y, Lengyel S, Nowicki P, Julliard R, Clobert J, Čelik T, Gruber B, Schmeller DS, Babij V, Henle K (2008) Integrating ongoing biodiversity monitoring: Potential benefits and methods. Biodiversity and Conservation 17(14): 3357-3382. https://doi.org/10.1007/ s10531-008-9417-1

Jansen JAM, Weeda EJ, Schippers P, Bijlsma RJ, Schaminée JHJ, Arts GHP, Deerenberg CM, Bos OG, Jak RG (2014) Habitattypen in Natura 2000-gebieden. Beoordeling van Oppervlakte, representativiteit en behoudsstatus in de Standard Data Forms (SDFs). Wageningen, Wettelijke Onderzoekstaken Natuur \& Milieu, WOt-technical report 8: 1-196. http:// edepot.wur.nl/314180

Lengyel S, Déri E, Varga Z, Horváth R, Tóthmérész B, Henry P-Y, Kobler A, Kutnar L, Babij V, Selskar A, Christia C, Papastergiadou E, Gruber B, Henle K (2008a) Habitat monitoring in Europe: A description of current practices. Biodiversity and Conservation 17(14): 3327-3339. https://doi.org/10.1007/s10531-008-9395-3

Lengyel S, Kobler A, Kutnar L, Framstad E, Henry P-Y, Babij V, Gruber B, Schmeller D, Henle $\mathrm{K}(2008 \mathrm{~b}) \mathrm{A}$ review and a framework for the integration of biodiversity monitoring at the habitat level. Biodiversity and Conservation 17(14): 3341-3356. https://doi.org/10.1007/ s10531-008-9359-7

Lengyel S, Kosztyi B, Schmeller DS, Henry P-Y, Kotarac M, Lin Y-P, Henle K (2018) Evaluating and benchmarking biodiversity monitoring: Metadata-based indicators for sampling design, sampling effort and data analysis. Ecological Indicators 85: 624-633. https://doi. org/10.1016/j.ecolind.2017.11.012

Mucina L, Bültmann H, Dierßen K, Theurillat J-P, Raus T, Čarni A, Šumberová K, Willner W, Dengler J, Gavilán García R, Chytrý M, Hájek M, Di Pietro R, Iakushenko D, Pallas J, Daniëls FJA, Bergmeier E, Santos Guerra A, Ermakov N, Valachovič M, Schaminée JHJ, Lysenko T, Didukh YP, Pignatti S, Rodwell JS, Capelo J, Weber HE, Solomeshch A, Dimopoulos P, Aguiar C, Hennekens SM, Tichý L (2016) Vegetation of Europe: Hierarchical floristic classification system of vascular plant, bryophyte, lichen, and algal communities. Applied Vegetation Science 19: 3-264. https://doi.org/10.1111/avsc.12257

Metzger MJ, Brus DJ, Bunce RGH, Carey PD, Gonçalves J, Honrado JP, Jongman RHG, Trabucco A, Zomer R (2013) The Environmental stratifications as the basis for national, European and global ecological monitoring. Ecological Indicators 33: 26-35. https://doi. org/10.1016/j.ecolind.2012.11.009

McConville AJ, Tucker GM (2015) Review of Favourable Conservation Status and Birds Directive article 2 interpretation within the European Union. Natural England Commissioned Reports 176: 1-106.

Moser D, Ellmauer T (2009) Konzept zu einem Monitoring nach Artikel 11 der Fauna-FloraHabitat-Richtlinie in Österreich. Im Auftrag der neun Bundesländer Österreichs. Umweltbundesamt, Wien, 1-131.

Riecken U, Finck P, Raths U, Schröder E, Ssymank S (2003) Standard-Biotoptypenliste für Deutschland, 2. Fassung: Februar 2003. Schriftenreihe für Landschaftspflege und Naturschutz 75: 1-65.

Sachteleben J, Behrens M (2010) Konzept zum Monitoring des Erhaltungszustandes von Lebensraumtypen und Arten der FFH-Richtlinie in Deutschland. BfN-Skripten (Bonn- 
Bad Godesberg) 278: 1-180. https://www.bfn.de/fileadmin/MDB/documents/service/ skript_278.pdf

Schmidt J, Fassnacht FE, Neff C, Lausch A, Kleinschmit B, Förster M, Schmidtlein S (2017) Adapting a Natura 2000 field guideline for a remote sensing-based assessment of heathland conservation status. International Journal of Applied Earth Observation and Geoinformation 60: 61-71. https://doi.org/10.1016/j.jag.2017.04.005

Stöhr O, Ragger C, Gewolf S, Drapela-Dhiflaoui J, Weinke E, Egger G, Lang S (2014) Basiserhebung von Lebensraumtypen und Arten von gemeinschaftlichen Bedeutung in Österreich. Natur und Landschaft 89(11): 471-477.

Vanden Borre J, Paelinckx D, Mücher CA, Kooistra L, Haest B, De Blust G, Schmidt AM (2011) Integrating remote sensing in Natura 2000 habitat monitoring: Prospects on the way forward. Journal for Nature Conservation 19(2): 116-125. https://doi.org/10.1016/j. jnc.2010.07.003

Vanden Borre J, Spanhove T, Haest B (2017) Towards a mature age of remote sensing for Natura 2000 habitat conservation: Poor method transferability as a prime obstacle. In: Díaz-Delgado F, et al. (Eds) The roles of remote sensing in nature conservation. Springer, 11-37. https://doi.org/10.1007/978-3-319-64332-8_2

Westra T, Onkelinx T, Oosterlynck P (2018) Design and implementation of a monitoring scheme to assess habitat quality of European protected habitats in Flanders (Belgium). Nature and Forest Research Institute (INBO). https://pureportal.inbo.be/portal/ files/15005144/thu_c_2_westra_2525.pdf

\section{Supplementary material I}

Table S1. Content of the questionnaire with explanations of the German approach Authors: Götz Ellwanger, Stephan Runge, Melanie Wagner, Werner Ackermann, Melanie Neukirchen, Wenke Frederking, Axel Ssymank, Ulrich Sukopp

Data type: table

Copyright notice: This dataset is made available under the Open Database License (http://opendatacommons.org/licenses/odbl/1.0/). The Open Database License $(\mathrm{ODbL})$ is a license agreement intended to allow users to freely share, modify, and use this Dataset while maintaining this same freedom for others, provided that the original source and author(s) are credited.

Link: https://doi.org/10.3897/natureconservation.29.27273.suppl1 